\title{
Royal Names in Medieval Ethiopia and their Symbolism
}

\author{
Ekaterina V. Gusarova \\ Institute of Oriental Manuscripts of the Russian Academy of Sciences; \\ National Library of Russia; National Research University Higher School \\ of Economics - St Petersburg, Russia \\ ekater-ina@mail.ru
}

\begin{abstract}
Millenarianism, widespread among Christians in general, was also deep-rooted in the flock of the Ethiopian Church. Several ideas of that kind occur in Ethiopic written sources. In particular, they appear in the treatise composed in Gəcəz language probably around the 16th-17th centuries AD. This work bears a title Fakkare Iyäsus ("The Explication of Jesus") and is dedicated to the last days of the World. Eschatological ideas about the appearance of a righteous King from the Orient became popular among the Ethiopian Christians and are well attested in royal chronicles. Chiliastic aspirations were prevalent during the period of political disintegration in the late 18th - mid-19th centuries AD known as the "Epoch of the Judges". The strong expectation for a graceful and powerful reign encouraged some clergymen to make prophecies. This tendency was manifested in the Ethiopian royal historiography and especially in royal onomastics.
\end{abstract}

\section{Keywords}

Royal onomastics - name symbolism - Millenarianism - Ethiopian clergy - Medieval Ethiopian Kingdom - Ethiopian royal chronicles - King Täklä Giyorgis I - Kings Tewodros (Theodore) I and II

The Christian influential religious doctrine, of millenarianism, (i.e. the belief in a coming transformation of society, after which "all things will be changed") also found many followers among the members of the 
Ethiopian Church in the Middle Ages. Even before the coming of Christianity to the Horn of Africa some beliefs probably connected with an eschatological role of the Aksumite monarch can be detected there. ${ }^{1}$ Additional evidence is found in Ethiopia's literary heritage, especially in the treatise called Fəkkare Iyäsus (The Explication of Jesus). The text written in Gəəəz deals with the last days of the World. ${ }^{2}$ The whole work is of a modest length and rather crudely written. Its main idea is that the God will destroy the mankind in the future as a punishment for disobedience to His command. The actual narration about Jesus commences with the episode of the Last Supper (Mt 26.17-30). The author brings forward the reasons for the God's dissatisfaction with the people and continues by describing the punishments that will follow inevitably.

After the detailed description of the punishments, which the sinners should expect for their depravity, the author continues by quoting the Divine Word: "I shall send a King called Tewodros (Theodore) from the Orient. He will bring with him those whom I take pity upon because they obey My orders. Among them will come a Metropolitan who will bless the Universe. The Churches now destroyed will be rebuilt as the result. Upon him, I shall bestow My blessing and My mercy". ${ }^{3}$ Then the anonymous author describes the reign of the Three Kings, etc.

Millenarian ideas as expressed in prophecies, which describe how the people expect the Last Days, were reflected in various cultural phenomena, including the Royal names. Usually, in addition to the Christian name received at the time of варtism and the so-called "throne" names, ${ }^{4}$ an Ethiopian King had also a kind of a "personal name" in the form of a sobriquet. It consisted of one or several words, which emphasized the King's personal qualities as a ruler, his piety and his standing towards the God and the Church. Such a sobriquet was normally considered as the King's second throne name. For example, the King 'Amdä Șəyon I (1314-1344), among others, had an official name Gäbrä Mäsqäl (i.e "The Slave of the Cross"). Similarly, Zär’a Ya 'əqob (1434-1468), David II

1 See for instance: G. Lusini, "Eschatology", in: Encyclopaedia Aethiopica, vol. 2, ed. S. Uhlig, Wiesbaden, 2005, p. 379 .

2 Published by I. Weinberg (И. Вайнберг (ed., transl.) «Сказание Иесуса». Апокриф о последних временах Мира [“The Explication of Jesus". An apocryphal narration regarding the Last Days of the World] (Monumenta Aethiopiae hagiologica, VI), St Petersburg, 1907. See: D. Nosnitsin, "Fəkkare Iyäsus", in: Encyclopaedia Aethiopica, vol. 2, ed. S. Uhlig, Wiesbaden, 2005, pp. 516-518.

3 И. Вайнберг, ор. cit., p. 2 .

4 M. Kleiner, "Regnal names", in: Encyclopaedia Aethiopica, vol. 3, ed. S. Uhlig, Wiesbaden, 2007, pp. 1122-1124. 
(1379/80-1413) and Täklä Giyorgis I ${ }^{5}$ were all called "Constantine", in honour of the Byzantine Emperor Constantine the Great. ${ }^{6}$ In this context, the regnal name Tewodros (Theodore) is of particular interest. In the Ethiopian Christian tradition, this name had a special millenarian connotation and was firmly associated with the apocalyptic treatise as mentioned above.

The first Ethiopian King who bore the name Tewodros was Tewodros I (1413-1414). He reigned only for a short period of nine months (12th of October, $1413^{-23 r d}$ of June, 1414), ${ }^{7}$ and died during a military campaign against Muslim troops of 'Adal sultanate.

Tewodros II (1855-1868), ${ }^{8}$ however, received his name in a direct connection with the Fəkkare Iyäsus. He is known for efforts to unify the country and to modernize it. Being of relatively humble origins, ${ }^{9}$ he, nevertheless, became an Emperor. In his case, the choice of his regnal name was not accidental, which confirm the milestones of his fight for power. Tewodros II is mentioned at the end of the list of Metropolitans of the Ethiopian Church, which is, among others, included in a manuscript copy of the Synaxarion written in Gə'əz. ${ }^{10}$ The following passage briefly describes how Tewodros II came to power: "The däğğazmac ${ }^{11}$ Kaśa met him as he was still a nobleman aspiring for power and discussed the question regarding the Faith. ${ }^{12}$ After the battle, he reigned, and they called him Theodore". Tewodros II was certainly the King who started the

Täklä Giyorgis I reigned for six different periods at the end of the 18th century AD (between 1779 and 1801).

6 D. AD 337.

$7 \quad$ M.-L. Derat, "Tewodros I", in: Encyclopaedia Aethiopica, vol. 4, ed. S. Uhlig with the cooperation of A. Bausi, Wiesbaden, 2010, pp. 929-930.

8 D. Crummey, D. Nosnitsin, E. Sokolinskaia, "Tewodros II", in: Encyclopaedia Aethiopica, vol. 4, ed. S. Uhlig with the cooperation of A. Bausi, Wiesbaden, 2010, pp. 930-936.

9 His original name was Kaśa Haylu; he was a son of a small feudal lord, however, his mother was of noble origin.

10 Ms. Däbrä Dammo DD-02o (C2-IV-265), Synaxarion, 1801-18 (digitized by the project Ethio-SPaReproject,https://www.aai.uni-hamburg.de/en/ethiostudies/research/ethiospare .html), catalogued by Magdalena Krzyzanowska, description accessed on https://mycms -vso3.rrz.uni-hamburg.de/domlib/receive/domlib_document_oooor619?genDesc=no\&i mages $=$ no\&phDesc $=$ no\&cnDesc $=0 \&$ col $=$ no\&add $=$ no\&decor $=$ no\&keywords $=$ no. Fol. $35 \mathrm{v}$, col. 2.15-36r, col. 3.28. See the edition of the list of Metropolitans in: E. V. Gusarova, "Joasaph II in an Unpublished list of the Metropolitans of the Ethiopian Church", in Scrinium. Journal of Patrology and Critical Hagiography (Leiden: E.J. Brill). Vol. 12. 2016, p. 25-34.

11 I.e. the "front squad commander"; one of the highest titles in Ethiopian military hierarchy.

12 The author refers to the Christian faith and local Ethiopian disputes of dogmatic character. The disputes occasionally arose among the clergy and led to splits and disintegration (spiritual and political). 
struggle for centralization of Ethiopia, but, because he did not spare any cruelty in achieving this goal, the memories of him were far from being laudatory.

Eschatological expectations of the Christians of Ethiopia became stronger during the time of political disintegration. Before 1855 different members of the royal dynasty and powerful feudal lords ruled simultaneously various parts of Ethiopia. At that time internal conflicts were incessant and they resulted in the destruction of the country and famine. No wonder, that the disorder and devastation increased the yearning of the population hopes for the time, when it would be put an end to the anarchy. When Täklä Giyorgis I in 1779 was enthroned for the first time, some people saw in him the great and just "king from the Orient" as mentioned in the Fəkkare Iyäsus. The first lines of the contemporary Ethiopian chronicle clearly demonstrate this attitude. ${ }^{13}$

Traditionally, the narration in each Ethiopian Royal chronicle commences with the praise and laudation to the new king. Such eulogies is often accompanied by allusions to the Scriptures. Among the names referred to in this context (Joshua, Constantine the Great, Alexander the Great, etc.) the name of Theodore (Tewodros) stands out. It is also significant that the chronicle about the reign of Täklä Giyorgis I commences with comparison of this monarch to Alexander the Great, and implies the name "Theodore". The historiographer (aläqa Gäbru ${ }^{14}$ ) called Täklä Giyorgis "the second Theodore"15 hinting at the messianic ruler mentioned in Ethiopian apocalyptic literature. According to the apocryphal legend, the righteous King would come to Earth before the Last Judgment and starts his rule, which would not be unjust. The author of the chronicle (aläqa Gäbru) tried to convince his audience that Täklä Giyorgis is worthy both of such a role and a name - thanks to his virtues. If a modern reader in this context discards the exaggerations and neglects the pompous

13 The chronicle is preserved in four copies in three collections of Ethiopian manuscripts (in London, Paris and Frankfurt am Main). An edition of its text was realized by H. Weld Blundell in 1922 (The Royal Chronicle of Abyssinia 1769-1840, with translation and notes by $\mathrm{H}$. Weld Blundell, Cambridge, 1922) which proved to be unsatisfactory from the philological point of view (not to speak of the translation he made with a probable assistance of Ethiopian (iterati). For the present research, I used the most complete and accurate copy from the British Library (Orient. 821, cf. W. Wright, Catalogue of the Ethiopic Manuscripts in the British Museum acquired since 1847, London, 1877, pp. 315-318).

14 The use of the title aläqa clearly shows that the author of the chronicle was a learned man and belonged to the clergy.

15 Naturally this expression does not mean that Tewodros I was the first Theodore; Täklä Giyorgis should be the second king bearing that name thus showing respect to the apocryphal Theodore. 
style, which were both rather typical for Ethiopian historiography he or she will receive a more or less adequate picture.

Täklä Giyorgis I succeeded in being the last Ethiopian sovereign of the Solomonic dynasty who had the real power in spite of strong centrifugal trends in the then Ethiopian society. He successfully campaigned against the infidels as well as various rebellious pagan tribes inhabiting the country, supported the Church and tried to maintain order in the unstable state. As a consequence Täklä Giyorgis I himself became a symbol for future generations. It is no coincidence that the governor of Lasta Gobäze, who tried to seize the baton of the country's unification after the death of Theodore II in 1868, adopted the name Täklä Giyorgis. ${ }^{16}$

The name of Tewodros applied to Täklä Giyorgis I also appears in the text of the chronicle concerning the description of the dinner given on the 21st of Yäkkatit (the 26th of February, AD 1783) to commemorate his victory over rebellious Oromo tribes and the conversion of some of their elders into Christianity. ${ }^{17}$ Several invitees used this festal occasion to praise the King. Their words were rendered in the chronicle in poetic form. As a result, two poems in the genre of $q \partial n e^{18}$ recited were recorded by aläqa Gäbru ${ }^{19}$ who also took part in the solemn dinner. Moreover, Gäbru himself authored the second poem. He used the name of Tewodros to glorify the sovereign. Below is the text and translation of the relevant fragment:

क夫

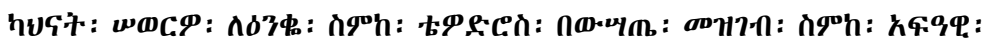

Thn: 2.P.C.n: Het:

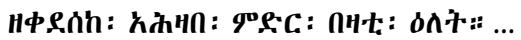

And after that aläqa Gäbru sang a qəne "Trinity":20

Priests hid the pearl of your name, Tewodros (Theodore), inside the treasury, i.e. inside your "external" (undisguised) name Täklä Giyorgis; (this is) the oil

With which peoples of the Earth anointed thee on that day ... ${ }^{21}$

16 Täklä Giyorgis II (1868-1871).

17 This military campaign took place from November 1782 to May 1783 .

18 Qəne is a kind of traditional religious poetry, used also on secular occasions.

19 Orient. 821, fol. 475v, col. 1.21-2.11 and col. 3.10-24.

20 Qəne are divided in different types according to structure. "Trinity" is the name of one of them.

21 See the original text in Orient. 821, fol. $475 \mathrm{v}$, col. 1.21-2.11. The edition of the text of this qane and its translation see in: The Royal Chronicle of Abyssinia 1769-1840..., pp. 57.27-29, 
The third qane to glorify the King was recited during another dinner, which took place on the same occasion several days later, on 25th of Yäkkatit (the 2nd of March, AD 1783) Its author was one of the clerics, who said:

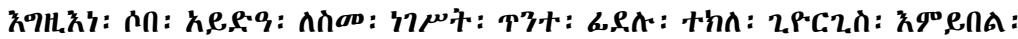

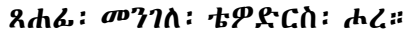

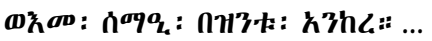

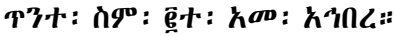

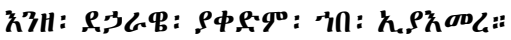

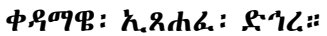

When our Lord made famous the initial sign of the royal name Täklä

Giyorgis, He said: "Everyone, who writes (it), holds also the path

to Tewodros,

And if (somebody) hears, let be surprised at this"...

When the beginning of the name united both (names),

He (i.e. the scribe) put the last of them forward, to where he did not know,

And did not write the first (of them). ${ }^{22}$

The Millenarian idea is clearly visible in these verses. The two authors emphasized by mentioning Theodore as the name of Täklä Giyorgis I that he was ordained by fate to become the last righteous king of Ethiopia (and the World community). The allusion to the second hidden name (that Täklä Giyorgis naturally did not have) is quite unconvincing, but it illustrates the attitude of the contemporaries of the king and his high authority among

284; its literal and poetic translation into Russian was made by Serge Frantsouzoff with reference to the inaccuracies of Blundell's publication (see C. А. Французов, “Три поэтических отрывка из хроники царя Эфиопии Такла Гиоргиса I” [Three poetic excerpts from the chronicle of the King of Ethiopia Täklä Giyorgis I], in: Manifesta Mетогаbilia. Проблемы истории и культуры стран Востока и Африки. Памяти Владимира Романовича Арсеньева [Problems of History and Culture of the Countries of the Orient and Africa. In Memoriam of Vladimir Romanovich Arseniev], St Petersburg, 2013, pp. 136-140 (pp. 130-143)). Here and below the literal translation of the relevant fragments is made directly from Gə`əz.

The original text see in: Orient. 821 , fol. $475 \mathrm{v}$, col. $3.10-24$. The edition of the text of this qone and its seriously distorted translation first published by H. Weld Blundell (The Royal Chronicle of Abyssinia 1769-1840..., pp. 58.4-8, 284-285) see in: С. А. Французов, ор. cit., pp. 141-143.

The allusion to Matthew 19.30 is obvious at the end of this poem. 
them. Hopes were pinned on him to put an end to political decentralization and disorder in the country.

Unfortunately, Täklä Giyorgis I did not succeed in preventing his state's collapse. He came to power, lost it and took it back again. After the last period of his rule, the country again plunged into 55 years of disorder and chaos.

Messianism was popular in medieval Ethiopia. Devout Ethiopians believed that their monarchs were anointed by God and, therefore, expected each of them to reign justly. Usually, the reality was very different from the expectations, the hope, however, was still there. Each sovereign, who was endowed with extraordinary qualities, could be considered as Messiah. Thereupon, he was awarded with special names that connoted an ideal ruler or the "Great King from the Orient" who would come to Earth before the Judgment Day. 